\title{
IMPLEMENTASI MANAJEMEN SUMBER DAYA MANUSIA DALAM MENINGKATKAN MUTU PENDIDIKAN DI SMK AL-FAQIH SUMBER NYAMPLONG KOWEL PAMEKASAN
}

\author{
Ach Nasrullah dan Moh Muchlis Solichin \\ Institut Agama Islam Negeri Madura, Jawa Timur, Indonesia \\ Email : anasyahreza8@gmail.com dan muchlisfiqhan@gmail.com
}

\begin{abstract}
Abstrak
Penelitian ini bertujuan untuk mengetahui implementasi manajemen sumber daya manusia dalam meningkatkan mutu pendidikan dan faktor yang mendukung terhadap implementasi manajemen sumber daya manusia dalam meningkatkan mutu pendidikan. Penelitian ini dilaksanakan di SMK Al-Faqih Sumber Nyamplong Kowel Pamekasan dengan menggunakan pendekatan kualitatif deskriptif. Hasil dari penelitian ini menunjukkan bahwa implementasi Manajemen Sumber Daya Manusia untuk Meningkatkan Mutu Pendidikan ada beberapa tahap diantaranya a) Analisis kebutuhan dan informasi, b) rekrutmen guru, c) induksi pegawai baru, d) penempatan guru, e) pemberian wewenang serta tanggung jawab terhadap staf, f) pelaksanaan supervisi, $g$ ) pembiaan kesejahteraan guru, $h$ ) pembinaan karir pegawai, i) pemutusan hubungan, dan j) pemberian pesangon. Sedangkan Faktor Yang Mendukung yaitu a) kepala sekolah memiliki banyak pertimbangan, b) program-program yang dijalankan di sekolah dapat membawa perubahan dan dampak positif, c) sarana dan prasarana dapat dimanfaatkan dengan maksimal, dan d) adanya evaluasi.
\end{abstract}

Kata Kunci : Manajemen, sumber daya manusia, mutu pendidikan

\begin{abstract}
This study aims to determine the implementation of human resource management in improving the quality of education and the factors that support the implementation of human resource management in improving the quality of education. This research was conducted at SMK Al-Faqih Sumber Nyamplong Kowel Pamekasan using a descriptive qualitative approach. The results of this study indicate that the implementation of Human Resource Management to Improve Education Quality has several stages including a) needs and information analysis, $b$ ) teacher recruitment, $c$ ) induction of new employees, d) teacher placement, e) granting authority and responsibility for staff, $f$ ) implementation of supervision, $g$ ) fostering teacher welfare, $h$ ) career development for employees, $i)$ termination of relations, and $j$ ) severance pay. While the Supporting Factors are a) principals have many considerations, b) programs run in schools can bring positive changes and impacts, c) facilities and infrastructure can be utilized optimally, and d) evaluation.
\end{abstract}

Keywords : Management, human resource, quality of education 


\section{PENDAHULUAN}

Pendidikan merupakan hal yang sangat penting dalam kehidupan. Tanpa pendidikan manusia akan mengalami kesulitan dalam keberlangsungan hidupnya. Pendidikan memiliki peranan yang sangat penting dalam kehidupan bermasyarakat, berbangsa, dan bernegara. Di mana tujuan pendidikan adalah membentuk manusia yang berakhlakul karimah, cerdas dan terampil serta beriman dan bertaqwa kepada tuhannya.

Pendidikan sesungguhnya memiliki peran yang sangat penting dalam kehidupan berbangsa dan bernegara, yakni dalam upaya menciptakan sumber daya manusia yang berkualitas. Pendidikan merupakan suatu faktor kebutuhan dasar untuk setiap manusia, karena melalui pendidikan upaya peningkatan kesejahteraan rakyat dapat diwujudkan. Pendidikan memengaruhi secara penuh pertumbuhan ekonomi suatu negara. Hal ini bukan saja karena pendidikan akan berpengaruh terhadap produktivitas, tetapi juga akan berpengaruh pada kemampuan masyarakat. Pendidikan dapat menjadikan sumber daya manusia lebih cepat mengerti dan siap dalam menghadapi perubahan dan pembangunan suatu negara. ${ }^{1}$

Pendidikan merupakan wadah untuk menampung dan menyalurkan ilmu-ilmu yang dimiliki oleh pendidik kepada peserta didik agar mempunyai pengetahuan yang luas, sikap atau tingkah laku yang baik. Dalam pendidikan juga tidak ada batasan usia ataupun ekonomi, karena semua orang berhak mendapatkan pendidikan tanpa adanya perbedaan siapa dan dari mana mereka berasal. Namun, terdapat banyak problem yang bisa menyebabkan pendidikan itu kurang merata, salah satunya ialah kurang mendapatkan mutu atau kualitas pendidikan yang setara, juga bisa dilihat dari Sumber Daya Manusianya. $^{2}$

Sumber daya merupaan aset utama yang diperlukan bagi pembangunan suatu bangsa, sumber daya tersebut ada dua macam yaitu sumberdaya alam (natural resouc), dan sumber daya manusia (human resources). Kedua sumber daya tersebut penting dalam menentukan keberhasilan suatu pembangunan. Sumber daya manusia memegang peran yang lebih penting dibandingkan dengan sumber daya yang lain. ${ }^{3}$

Ika dalam Ariny mengatakan bahwa rendahnya kualitas sumber daya manusia merupakan masalah mendasar yang dapat menghambat pembangunan dan perkembangan ekonomi nasional. Oleh karena itu, diperlukan sumber daya manusia berkualitas yang memiliki kemauan dan kemampuan untuk senantiasa meningkatkan kualitasnya secara terus menerus dan berkesinambungan (continuous quality improvement). ${ }^{4}$

Pengertian manajemen sumber daya manusia bila dikaitkan dalam bidang pendidikan adalah ilmu dan seni yang mengatur proses pemanfaatan sumber daya

\footnotetext{
${ }^{1}$ I Ketut Sudarsana, "Peningkatan Mutu Pendidikan Luar Sekolah Dalam Upayapembangunan Sumber Daya Manusia,” Jurnal Penjaminan Mutu 1, no. 1 (2016): 1, https://doi.org/10.25078/jpm.v1i1.34.

${ }^{2}$ Maryatul Wakiah and Jamiludin Usman, "Manajemen Peningkatan Mutu Kompetensi Lulusan Bidang Kewirausahaan Dalam Memenuhi Standar Nasional Pendidikan Di Smk Annuqoyyah Guluk-Guluk Sumenep Jawa Timur,” Re-JIEM (Research Journal of Islamic Education Management) 3, no. 1 (2020): 72, https://doi.org/10.19105/re-jiem.v3i1.3517.

${ }^{3}$ Mohammad Thoha, Manajemen Penddikan Islam Konseptual Dan Operasional (Surabaya: Salsabila Putra Pratama, 2016), 48.

${ }^{4}$ Robby Arini and Achmad Muhlis, "Manajemen Strategik Mutu Rekrutmen Tenaga Kependidikan Di Institut Agama Islam Negeri Madura," Re-JIEM (Research Journal of Islamic Education Management) 3, no. 1 (2020): 30, https://doi.org/10.19105/re-jiem.v3i1.3485.
} 
manusia dalam institusi pendidikan, seperti kepala sekolah, guru, dan sumber-sumber lainnya secara efektif dan efisien untuk mencapai suatu tujuan pendidikan secara optimal. Dengan manajemen sumber daya manusia dalam pendidikan, pencapaian tujuan pendidikan akan terwujud. Selain itu, juga akan dihasilkan output pendidikan yang memiliki life skill yang tinggi, serta memiliki komperensi dibidang akademik maupun nonakademik. ${ }^{5}$

Pengelolaan sumber daya manusia pada dasarnya merupakan deskripsi dari administrasi atau manajemen pendidikan dengan mengedentifikasi fungsinya sebagai suatu proses administrasi dan manajemen pendidikan yang didesain untuk saling berkaitan antara tujuan individu maupun organisasi. Bagi suatu organisasi, pengelolaan sumber daya manusia menyangkut keseluruhan urusan organisasi dan tujuan yang telah ditetapkan dengan memaksimalkan kinerja para karyawan atau staf. ${ }^{6}$

Berdasarkan pendapat di atas dapat disimpulkan, Ketika lembaga pendidikan formal maupun nonformal lembaga tersebut dapat menjalanjan (mengimplentasi) Sumber Daya Manusia yang ada, juga ketika lembaga pendidikan tersebut dapat menerapkan dengan sistematik dan optimal maka akan berdampak positif terhadap mutu sekolah itusendiri baik dari segi kualitas maupun kuantitas sudah tidak akan diragukan lagi oleh masyarakat.

Sekolah atau madrasah sebagai lembaga lembaga pendidikan harus selalu berbenah diri agar menjadi berkualitas dan memiliki daya saing yang tinggi. Hali ini menunjukkan bahwa inovasi dan kreativitas dalam mengelola lembaga pendidikan harus berjalan secara terus-menerus sejalan dengan laju pertumbuhan dan perkembangan ilmu pengetahuan. Mutu pendidikan menjadi perhatian utama dalam mengelola sekolah/madrasah. Sekolah yang bermutu akan dapat memuaskan pelanggan atau pengguna dari jasa pendidikan ini. Untuk mengelola madrasah yang berkualitas diperlukan otonomi dan kreativitas sekolah/madrasah. Dalam konteks ini, di Indonesia telah diterapkan Manajemen Peningkatan Mutu Berbasis Sekolah/Madrasah. Implementasi manajemen peningkatan mutu berbasis sekolah dititikberatkan pada bagaimana sekolah atau madrasah dapat mengoptimalkan kinerja organisasi sekolah, proses pembelajaran, pengelolaan sumber daya manusia, dan pengelolaan sumberdaya sekolah dan administrasi. ${ }^{7}$

\section{METODE PENELITIAN}

Dalam penelitian ini, penulis menggunakan pendekatan kualitatif. Menurut Bogdan dan Taylor "Bahwa pendekatan kualitatif merupakan proses penelitian yang menghasilkan data deskriptif yang berupa kata-kata tulisan atau lisan dari orang dan perilaku yang dapat diamati", 8

Penelitian ini memakai pendekatan kualitatif karena bertujuan untuk menyajikan dunia sosial, dan perspektifnya di dalam dunia, dari segi konsep, perilaku, persepsi dan persoalan tentang manusia yang diteliti. Selain itu dengan pendekatan ini diharapkan

\footnotetext{
${ }^{5}$ Thoha, Manajemen Penddikan Islam Konseptual Dan Operasional, 48.

6 Thoha, 48.

${ }^{7}$ Prim Masrokan Mutohar, Anajemen Mutu Sekolah Strategi Peningkatan Mutu Dan Daya Saing Lembaga Pendidikan Islam (Yogyakarta: Ar Ruzz Media, 2013), 159.

${ }^{8}$ Lexy J. Moleong, Metodologi Penelitian Kualitatif (Bandung: Remaja Rosdakarya, 2011), 4.
} 
peneliti akan lebih dekat pada subjek penelitian yang akan diteliti serta lebih peka dan akan lebih berinteraksi dalam penyesuaian diri.

Penelitian ini berusaha mengkaji secara mendalam tentang Implementasi manajemen sumber daya manusia dalam meningkatkan mutu pendidikan dengan menggunakan beberapa prosedur pengumpulan data tentang Implementasi manajemen sumber daya manusia dalam meningkatkan mutu pendidikan di SMK Al-Faqih sumber Nyamplong Kowel Pamekasan. Dengan demikian, maka dapat diuraikan secara mendalam. Pengumpulan data yang digunakan dalam penelitian ini ada tiga yaitu: observasi, wawancara, dan dokumentasi. Dalam penelitian ini peneliti menggunakan observasi non partisipan dimana peneliti hanya jadi pengamat. Peneliti merupakan outsider dari kelompok yang sedang diteliti, menyaksikan dan membuat catatan lapangan dari kejauhan. Wawancara yang digunakan adalah jenis wawancara tidak terstruktur hal ini bertujuan agar peneliti dapat mananyakan lebih mendalam tentang penelitian yang dilakukan.

Dokumentasi digunakan untuk memperkuat data-data dari proses wawancara dan dokumentasi. Data yang digunakan dalam penelitian ini ada dua yaitu, data primer dan skunder. Data primer peneliti peroleh dari kepala sekolah yang merupakan pimpinan,guru yang merupakan pelaksana dan perencana atas program-program sekolah.Informanpenelitian ini adalah kepala sekolah, tenaga pendidik di SMK AlFaqih Sumber Nyamplong Kowel Pamekasan. Sedangkan pengecekan keabsahan data dilakukan melalui perpanjangan keikut sertaan, ketekunan pengamatan dan triangulasi.

\section{HASIL DAN PEMBAHASAN}

\section{Implementasi Manajemen Sumber Daya Manusia Dalam Meningkatkan Mutu Pendidikan Di SMK Al-Faqih Sumber nyamplong Kowel pamekasan}

Dari paparan data dan temuan penelitian tersebut, peneliti dapat melakukan pembahasan mengenai dua fokus penelitian ini.

Ada beberapa hal yang harus diperhatikan oleh pengelola lembaga pendidikan dalam meningkatkan mutu pendidikan yang perlu diterapkannya utamanya dalam penerapan manajemen sumber daya manusia. Hal ini sangat dibutuhkan dalam meningkatkan mutu suatu sekolah atau pendidikan. Dalam proses pelaksanaan implementasi manajemen sumber daya manusia yang perlu di perhatikan yaitu analisis kebutuhan dan informasi.

Menurut Richard A. Gorton yang dikutip oleh Mohammad Thoha dalam bukunya yang berjudul manjemen pendidikan islam konseptual dan operasional menyebutkan bahwa analisis kebutuhan merupakan dasar dalam penyusuna formasi. Analisis kebutuhan pegawai adalah suatu proses perhitungan secara logis dan teratur dari segala faktor-faktor yang ditentukan untuk dapat menentukan jumlah dan susunan pangkat pegawai yang dibutuhkan oleh suatu organisasi. Sedangkan formasi adalah jumlah pangkat yang diperlukan dalam satuan organisasi untuk mampu melaksanakan tugas pokok dalam jangka waktu tertentu. ${ }^{9}$

Dalam meningkatkan mutu pendidikan perlu diterapkannya manajemen sumber daya manusia. Hal ini sangat dibutuhkan dalam meningkatkan mutu suatu sekolah atau pendidikan. Dalam proses pelaksanaan implementasi manajemen sumber daya

\footnotetext{
${ }^{9}$ Thoha, Manajemen Penddikan Islam Konseptual Dan Operasional, 50.
} 
manusia yang perlu di perhatikan adalah perekrutan calon guru. Rekruitmen yang efektif dipengaruhi oleh bagaimana organisasi dapat melaksanakan sejumlah kegiatan ini didalam proses tersebut.

Menurut Stoner, kegiatan yang dilaksanakan dalam proses rekrutmen adalah sebagai berikut: (1) Menentukan dan membuat kategori kebutuhanSumber Daya Manusia jangkapendek dan jangka panjang.(2) Selalu memperhatikan perubahan kondisi didalam pasar tenaga kerja.(3) Mengembangkan media (promosi) rekruitmen yang paling sesuai untuk menarik parapelamar. (3) Menyimpan data tentang jumlah dan kualitas peramal pekerjadari setiap sumber. (4) Menindak lanjuti dari setiap permohonan pelamar kerja untuk kemudian melakukan evaluasi efektivitas dengan upaya rekruitmen yang telah dilakukan. ${ }^{10}$

Ketika kegiatan rekrutmen selesai tahap selanjutnya yang akan di lakukan oleh sekolah yaitu induksi pegawai baru atau yang disebut juga dengan kegiatan orientasi atau pengenalan tempat kerja bagi pegawai yang baru saja di rekrut oleh lembaga.

Menurut Mohammad Thoha dalam bukunya yang berjudul manjemen pendidikan islam konseptual dan operasional menyebutkan dalam proses induksi pegawai baru, langkah yang dilakukan pertama kali ialah pengenalan. Pengenalan hal yang dilakukan meliputi pengenalan visi dan misi sekolah, tanggung jawab bagi pegawai dan proses penyesuaian dengan lingkungan sekolah karena sekolah tersebut masih berstatus pesantren maka guru dituntut untuk bisa menyesuaikan diri. ${ }^{11}$

Setelah kegiatan orientasi atau pengenalan selesai tahap selanjutnya yang akan di lakukan oleh sekolah yaitu sesuai dengan arahan yang di suruh oleh kepala sekolah tentang penempatan guru. Penempatan pegawai merupakan tindak lanjut dari seleksi.

Menuurut Dr. Rohiat sekolah harus menentukan penanggung jawab suatu kegiatan/program, kelompok program dan atau keseluruhan program. Dengan SK Kepala Sekolah, tiap orang atau kelompok dapat menjadi penanggung jawab atau anggota pelaksana program/kegiatan. Pertimbangan utamanya adalah profesionalitas, kesesuaian, kewenangan, kemampuan, kesediaan dan kesempatan yang ada, asa proporsionalitas bisa dipertimbangkan kemudian. ${ }^{12}$

Setelah penempatan pegawai selesai langkah selanjutnya yang di terapkan di sekolah yaitu Pemberian wewenang serta tanggung jawab pada guru hal ini merupakan langkah selanjutnya yang di lakukan oleh kepala sekolah dalam upaya manajemen Sumber adaya manusia dalam meningkatkan mutu pendidiakan.

Menurut Suparlan, dalam bukunya yang berjudul Menjadi Guru efektif dijelaskan bahwa kejelasan tentang hak dan kewajiban ini sangat diperlukan untuk dapat memberikan jaminan terhadap penghargaan dan perlindungan guru sebagai tenaga profesi, termasuk di dalamnya perlindungan hukum. Meskipun hak dan kewajiban guru menjadi wacana yang mengemuka, para guru masih akan tetap

10 Rohmatun Lukluk Isnaini, “Implementasi Rekrutmen Guru Disd Ta’Mirul Islam Surakarta (Kajian Manajemen Sumber Daya Manusia Di Sd Islam)," Jurnal Pendidikan Agama Islam 12, no. 1 (2015): 3-4, https://doi.org/10.14421/jpai.2015.121-08.

11 Thoha, Manajemen Penddikan Islam Konseptual Dan Operasional, 54.

12 Rohiat, Manajemen Sekolah (Bandung: PT. Refika Aditama, 2010), 112. 
konsisten dengan prinsip bahwa hak-hak para guru akan diperoleh setelah kewajibannya dilaksanakan dengan baik, profesional, dan bertanggung jawab. ${ }^{13}$

Selain pemberian wewenang serta tanggung jawab pada staf. Di SMK Al-Faqih Kowel Pamekasan disini tidak hanya menerapkan pemberian wewenang dan tanggung jawab saja. Namun juga mengelola bagaimana meningkatkan kinerja guru mengingat standar beban kinerja yang diberikan kepada guru yang menjadi tolok ukur keberhasilan hal tersebut. seperti yang diungkapkan oleh Bapak Zainullah, S.Pd.I SMK Al-Faqih Sumber Nyamplong kowel Pamekasan, sebagaimana petikan wawancara berikut." Pelaksanaan supervisi dilakukan untuk melakukan evaluasi dan perbaikan sesuai dengan kekurangan yang terjadi di lapangan. Baik yang berkenaan dengan Manajemen Pendidikan, kegiatan belajar mengajar atau ketersediaan sarana dan prasarana yang dibutuhkan. Dengan demikian kita dapat mengetahui sejauh mana hasil kerja bawahan selama ini secara prosentase. Setelah itu kita dapat melakukan strategi yang lebih efektif untuk para pegawai agar bisa meningkatkan hasil kinerjanya."

Menurut M. Ngalim Purwanto dalam bukunya yang berjudul administrasi dan Supervisi Pendidikan mengatakan bahwa tugaskewajiban kepala sekolah, disamping mengatur jalannya sekolah, juga harus dapat bekerja sama dan berhubungan erat dengan masyarakat. Ia berkewajiabn membangkitkan semangat staf guru-guru dan pegawai sekolah untuk bekerja lebih baik, membangun dan memelihara kekeluargaan, kekompakan dan persatuan antara guru-guru, pegawai dan muridmuridnya, mengembangkan kurikulum sekolah, mengetahui rencana sekolah dan tahu bagaimana menjalankan, memperhatikan dan mengusahakan kesejahteraan guru-guru dan pegawai-pegawainya dan sebagainya. ${ }^{14}$

Pembinaan kesejahteraan guru merupakan langkah selanjutnya yang di lakukan oleh kepala sekolah dalam upaya manajemen Sumber adaya manusia dalam meningkatkan mutu pendidiakan. Seperti yang diungkapkan oleh Bapak Zainullah, S.Pd.I SMK Al-Faqih Sumber Nyamplong kowel Pamekasan, sebagaimana petikan wawancara berikut." Dalam pembinaan kesejahteraan Guru ini, saya lakukan untuk meningkatkan kualitas dan kompetensi guru agar profesional dalam melakukan tugas yang menjadi suatu tanggung jawab terhadap guru yang bersangkutan.

Menurut Muhammad Thoha dalam Bukunya yang berjudul Manajemen pendidikan islam Konseptual dan operasional mengungkapkan bahwa perencanaan dan pembinaan karir pegawai sangat diperlukan, agar pengembangan organisasi kedepan sejalan dengan pengembangan kemampuan bagi para pegawai yang akan menduduki jabatan organisas yang telah berkembang tersebut. ${ }^{15}$

Pembinaan karir guru merupakan langkah selanjutnya yang di lakukan oleh kepala sekolah dalam upaya manajemen Sumber adaya manusia dalam meningkatkan mutu pendidiakan.

Menurut Suparlan, dalam bukunya yang berjudul Guru Sebagai Profesi menjelaskan : program pembinaan guru, dapat dijelaskan bahwa upaya peningkatan kompetensi Guru secara sistematik. Kebijakan peningkatan mutu guru pada tahap

13 Suparlan, Menjadi Guru Efektif (Yogyakarta: Hikayat Publishing, 2005), 44.

14 M. Ngalim Purwanto, Administrasi Dan Supervisi Pendidikan (Bandung: Remaja Rosdakarya, 2010), 75.

15 Thoha, Manajemen Penddikan Islam Konseptual Dan Operasional, 61. 
awal ini memang dilaksanakan dalam berbagai bentuk pendidikan di lembaga pendidikan tenaga kependidiakan (Preservice educationI), pendidikan dan Pelatian (inservice training), dan On The Job Training ( pendidikan dalam jabatan) ketiganya merupakan sub sistem pembinaan guru yang tidak dapat dipisahkan antara satu dengan yang lain. ${ }^{16}$

Kepala sekolah sebagai pemangku kebijakan memiliki peran penting dalam memutuskan suatu hal yang terjadi. Misalkan dari segi program-program yang tidak berjalan secara maksimal akan di adakan evaluasi bersama dan juga mengenai pendidik dan tenaga pendidik yang tidak maksimal dalam melaksanakan tugas yang diembannyan nntinya juga akan dilakukan supervisi dan evaluasi apakah pendidik dan tenaga pendidik tersebut masih mau dipertahankan atau malah sebaliknya yaitu pemutusan hubungan kerja. Langkah selanjutnya yaitu pemutusan hubungan kerja yang dilakukan oleh kepala sekolah. Hal ini sesuai dengan hasil wawancara dengan kepala sekolah SMK Al-Faqih Sumber Nyamplong Kowel Pamekasan, sebagaimana petikan wawancara berikut ini.

"Pemberhentian tenaga kerja dilingkungan satuan pendidikan kami tidak dilakukan secara mendadak. Dari sederet hasil supervisi dan evaluasi kita memiliki acuan untuk lebih meningkatkan potensi kerja para pendidik dan tenaga kependidikan. Usaha peningkatan itu kita lakukan selama Surat Keputusan untuk para bawahan masih berlaku selama satu tahun. Selama satu tahun itu kami memiliki tanggung jawab untuk membimbing, mengarahkan, memperbaiki, memeberikan masukan, kepada para pegawai agar menjadi lebih baik."

Pesangon merupakan uang yang diberikan kepada guru sebagai tanda trimakasih sekolah selama menjadi bagian dari satuan organisasi. Selain Pemutusan hubungan kerja pegawai juga yang harus di perhatikan yaitu pemberian pesangon terhadap Guru. Hal ini di paparkan oleh kepala Sekolah yaitu Bapak Zainullah, S.Pd.I SMK Al-Faqih Sumber Nyamplong kowel Pamekasan, sebagaimana petikan wawancara berikut :'Pesangon diberikan kepada pegawai yang berhenti atau diberhentikan secara terhormat. Pemberian pesangon ini mengacu pada AD/ART Yayasan untuk memberikan bekal kepada pegawai yang berhenti bekerja sebelum mendapatkan pekerjaan yang baru."

\section{Faktor Implementasi Manajemen Sumber Daya Manusia Dalam Meningkatkan Mutu Pendidikan Di SMK Al-Faqih Sumber nyamplong Kowel pamekasan}

Mutu atau kualitas adalah gambaran dan karakteristik menyeluruh dari barang atau jasa yang menunjukkan kemampuannya dalam memuaskan kebutuhan yang diharapkan mutu yang baik akan memuaskan pelanggan atau pengguna dari jasa tersebut. Dalam pengimplementasi MSDM ada faktor yang mendukung terhadap peningkatan mutu pendidikan sepertihalnya program yang di jalankan di suatu lembaga pendidikan.

Di SMK Al-Faqih Sumber Nyamplong, faktor yang mendukung terhadap mutu pendidikan dalam suatu lembaga dapat dilihat dari program-program apa saja yang di tawarkan di suatu lembaga. Semakin banyak program yang di tawarkan, semakin

\footnotetext{
${ }^{16}$ Suparlan, Menjadi Guru Efektif, 118.
} 
banyak pula dampaknya tehadap peningkatan mutu di sekolah tersebut dan program tersebut selaras dengan visi misi sekolah, sehingga ada konektivitas antara lembaga dengan mutu pendidikan. Dari pemaran diatas bahwa faktor yang mendukung terhadap mutu pendidikan dalam suatu lembaga dapat dilihat dari program-program apa saja yang di tawarkan di suatu lembaga. Semakin banyak program yang di tawarkan, semakin banyak pula dampaknya tehadap peningkatan mutu di sekolah tersebut dan program tersebut selaras dengan visi misi sekolah, sehingga ada konektivitas antara lembaga dengan mutu pendidikan.

Selain itu, Sarana dan prasarana pendidikan merupakan suatu aset penting dalam suatu pendidikan. Karena sarana dan prasarana menjadi alat penunjang dalam suatu proses keberhasilan suatu pendidikan.

Sesuai dengan yang diungkapkan Barnawi dan M.arifin bahwa sebagai lembaga pendidikan, sekolah memerlukan dukungan sarana dan prasarana pendidikan. Sarana dan prasarana pendidikan merupakan materia pendidikan yang sangat penting. Banyak sekolah memiliki sarana dan prasarana pendidikan yang lengkap sehingga sangat menunjang proses pendidikan di sekolah. Baik guru maupun siswa, merasa terbanttu dengan adanya fasilitas tersebut. Namun sayangnya, kondisi tersebut tidak berlangsung lama. Tingkat kualitas sarana dan prasarana tidak dapat dipertahankan secara terus-menerus. Sementara itu, bantuan sarana dan prasarana pun tidak datang setiap saat. Oleh karena itu, dibutuhkan upaya pengelolaan sarana dan prasarana secara baik agar kualitas dan kuantitas sarana dan prasarana dapat dipertahankan dalam waktu yang relatif lama. ${ }^{17}$

Berdasarkan temuan penilitian yang dilaksanakan di SMK Al-Faqih sumber nyamplong kowel pamekasan, berkaitan dengan sarana dan prasarana di SMK AlFaqih Secara fisik sudah memadai meskipun secara umum tidak seratus perses maksimal, mulai dari ruang kelas yang representatif, tersedianya ruang guru, kemudian ruang administrasi dan ruang kantor. Secara khusus mengenai sarana dan prasarana yang berhubungan dengan kejuruan sekitar delapan puluh persen sudah memadai karena di SMK Al-Faqih sudah disediakan lab komputer, perpustakaan dan lab ipa yang tersedia di SMK Al-Faqih.

Dari pemaparan di atas bahwa sarana prasarana merupakan instrumen yang penting dalam suatu pendidikan demi meningkatkan kualitas proses pembelajaran serta salah satu daya tarik bagi calon peserta didik yang akan sekolah di suatu lembaga.

Selain itu, Kurikulum merupakan ciri utama pendidikan di sekolah. dengan kata lain, kurikulum merupakan syarat mutlak bagi pendidikan di sekolah dan kurikulum bagiaan yang takterpisahkan dari pendidikan atau pengajaran.

Menurut Sukmadinata, untuk menjamin mutu hasil pendidikan, desain dan implementasi kurikulum selalu dievaluasi dan disempurnakan. Evaluasi dan penyempurnaan kurikulum ini dilakukan secara menyeluruh, atau pada bagianbagian tertentu, secara berkala atau insidental, secara serempak melibatkan semua guru atau dikerjakan oleh tiap-tiap guru. Kurikulum ini selalu mengalami proses

17 Barnawi and M. Arifin, Manajemen Sarana \& Prasarana Sekolah (Yogyakarta: Ar Ruzz Media, 2014), 47. 
penyempurnaan. ${ }^{18}$ Dalam menjamin mutu hasil pendidikan, desain dan implementasi kurikulum selalu di evaluasi dan disempurnakan. Evaluasi dan penyempurnaan kurikulum ini dilakukan secara menyeluruh, atau pada bagian-bagian tertentu, secara berkala atau insidental, secara serempak melibatkan semua guru atau dikerjakan oleh tiap-tiap guru. Kurikulum ini selalu mengalami proses penyempurnaan. ${ }^{19}$

Berdasarkan temuan penilitian yang dilaksanakan di SMK Al-Faqih sumber nyamplong kowel pamekasan. Di SMK Al-Faqih di sana penerapn kurikulum dalam proses pembelajaran sudah berjalan dengan maksimal dan mengikuti saran dari pemerintah. Kebetulan SMK Al-Faqih sudah mendapatkan SK kelayakan untuk menerapkan kurikulum K13 di Kelas X Tahun pelajaran 2017-2018. Sedangkan untuk kelas XI dan XII kurikulum yang di pakai masih kurikulum KTSP 2006. Namun dua kurikulum tersebut tetap bisa diterapkan karena guru-gurunya udah pernah mengikuti bimbtek K13 dan KTSP 2006. Di samping itu tersedianya alat-alat, sumber dan media pembelajaran juga ikut serta membantu dalam menciptakan efektifitas pembelajaran di dalam kelas dan di luar kelasDi SMK Al-Faqih di sana penerapn kurikulum dalam proses pembelajaran sudah berjalan dengan maksimal dan mengikuti saran dari pemerintah. Kebetulan SMK Al-Faqih sudah mendapatkan SK kelayakan untuk menerapkan kurikulum K13 di Kelas X Tahun pelajaran2017-2018. Sedangkan untuk kelas XI dan XII kurikulum yang dipakai masih kurikulum KTSP 2006. Namun dua kurikulum tersebut tetap bisa di terapkan karena guru-gurunya udah pernah mengikuti bimbtek K13 dan KTSP 2006. Disamping itu tersedianya alat-alat, sumber dan media pembelajaran juga ikut serta membantu dalam menciptakan efektifitas pembelajaran di dalam kelas dan di luar kelas.

Dari pemaparan di atas bahwa kurikulum memiliki peran yang sangat penting dalam keseluruhan kegiatan pembelajaran serta menjadi penentu proses kegiatan belajar mengajar serta hasil pendidikan. Oleh sebab itu perencanaa, pengorganisasian, pelaksanaan, dan evaluasi kurikulum merupakan sesuatu yang harus di lakukan dan dipersiapkan dengan matang oleh setiap lembaga pendidikan (sekolah).

Dalam mengevaluasi kinerja dan program-program yang di terapkan di lembaga pendidikan yang seharusnya dilakukan oleh pimpinan, namun terkadang diabaikan begitu saja. Hal ini sering terjadi pada lembaga pendidikan swasta sehingga membuat para MSDM tidak mengalami perkembangan artinya hanya stagnan disitu saja.

Menurut Irawan dalam bukunya yang berjudul Evaluasi Kinerja Sumber Daya Manusia mengatakn Dalam setiap lembaga pendidikan, kepala sekolah memerlukan sumber daya untuk mencapai tujuannya. Sumber daya merupakan energi, tenaga, kekuatan (power) yang diperlukan untuk menciptakan daya, gerak, aktivitas, kegiatan, dan tindakan. Sumber daya tersebut antara lain terdiri atas sumber daya alam, sumber daya finansial, sumber daya manusia, sumber daya pengetahuan, dan sumber daya teknologi. Di antara sumber daya tersebut, sumber daya yang terpenting adalah sumber daya manusia (SDM-human resources). Sumber daya Manusia

18 Nana Syaodih Sukmadinata, Ayi Novi Jami'at, and Ahman, Pengendalian Mutu Pendidikan Sekolah Menengah: Konsep, Prinsip, Dan Instrumen (Bandung: Refika Aditama, 2006), 19.

19 Sukmadinata, Jami' at, and Ahman, 19. 
merupakan daya yang digunakan untuk menggerakkan dan menyinergikan sumber daya lainnya untuk mencapai tujuan organisasi. ${ }^{20}$

Dari pemaparan di atas bahwa evaluasi merupakan salah satu dari tiga komponen hal yang tidak bisa di pisahkan. Diantara komponen tersebut yaitu. Perencanaan, pelaksanaan, dan evaluasi. Dari ketiganya tersebut harus berkesinambungan agar supaya sistem pendidikan dalam suatu lembaga dapat berjalan secara optimal.

\section{KESIMPULAN}

Dari berbagai penjabaran diatas maka peneliti akan menarik kesimpulan yang disesuaikan dengan rumusan masalah yang telah ditentukan diantaranya sebagai berikut:

Dalam pengimplementasian Manajemen Sumber Daya Manusia untuk Meningkatkan Mutu Pendidikan di Di SMK Al-Faqih Sumber Nyamplong Kowel Pamekasan meliputi beberapa tahap diantaranya yaitu : a) analisis kebutuhan dan informasi, b) rekrutmen guru, c) induksi pegawai baru yang mana bertujuan ontuk pengenalan bursa kerja yang baru, d) penempatan guru, e) pemberian wewenang serta tanggung jawab terhadap staf agar dapat semaksimal mungkin dalam melaksanakan tugas, f) pelaksanaan supervisi terhadap kinerja pegawai. g. yang ketujuh yaitu pembiaan kesejahteraan guru, g) pembinaan karir pegawai. Adapun dalam pembinaan pegawai dalam upaya meningkatkan kualitas dan kompetensi guru agar berkualitas, h) pemutusan hubungan, dan i) pemberian pesangon.

Faktor Yang Mendukung Terhadap Implementasi Manajemen Sumber Daya Manusia Dalam Meningkatkan Mutu Pendidikan di SMK Al-Faqih Sumber Nyamplong Kowel Pamekasan yaitu a) kepala sekolah memiliki banyak pertimbangan baik yang berkaitan dengan kurikulum yang digunaka dapat berkembang secara maksimal, sehingga mendapatkan hasil yang memuaskan, b) adanya program-program yang dijalankan di sekolah tersebut dapat membawa perubahan dan damak positif untuk meningkat mutu pendidikan, c) adanya sarana dan prasarana bertujuan untuk kegiatan belajar mengajar dapat dimanfaatkan dengan maksimal, dan d) adanya evaluasi yang bertujuan untuk mengetahui tingkat keberhasilan yang dicapai dalam penerapan semua program-program yang telah dilaksanakan. Dari keempat faktor tersebut dapat diharapkan meningktakan kualitas/mutu pendidikan di lembaga pendidikan, khususnya di SMK Al-Faqih Sumber Nyamplong Kowel Pamekasan.

Berdasarkan kesimpulan yang telah dipaparkan di atas, maka selanjutnya peneliti menyampaikan saran-saran yang kiranya dapat bermanfaat kepada pihak-pihak yang terkait atas hasil penelitian ini. Bagi pihak SMK Al-Faqih Sumber Nyamplong Kowel Pamekasan diharapkan dapat meningkatkan Manajemen Sumber Daya Manusia dan Mutu Pendidikan. Bagi Masyarakat Umum, diharapkan bisa menjadi acuan dalam menilai manajemen sumber daya manusia dalam meningkatkan mutu pendidikan, khususnya di SMK Al-Faqih Sumber Nyamplong Kowel Pamekasan.

20 Wirawan, Evaluasi Kinerja Sumber Daya Manusia Teori, Aplikasi,Dan Penelitian (Jakarta: Selemba Empat, 2009), 1. 


\section{DAFTAR PUSTAKA}

Arini, Robby, and Achmad Muhlis. "Manajemen Strategik Mutu Rekrutmen Tenaga Kependidikan Di Institut Agama Islam Negeri Madura." Re-JIEM (Research Journal of Islamic Education Management) 3, no. 1 (2020): 29. https://doi.org/10.19105/re-jiem.v3i1.3485.

Barnawi, and M. Arifin. Manajemen Sarana \& Prasarana Sekolah. Yogyakarta: Ar Ruzz Media, 2014.

Lukluk Isnaini, Rohmatun. "Implementasi Rekrutmen Guru Disd Ta'Mirul Islam Surakarta (Kajian Manajemen Sumber Daya Manusia Di Sd Islam)." Jurnal Pendidikan Agama Islam 12, no. 1 (2015): 109-20. https://doi.org/10.14421/jpai.2015.121-08.

Moleong, Lexy J. Metodologi Penelitian Kualitatif. Bandung: Remaja Rosdakarya, 2011.

Mutohar, Prim Masrokan. Anajemen Mutu Sekolah Strategi Peningkatan Mutu Dan Daya Saing Lembaga Pendidikan Islam. Yogyakarta: Ar Ruzz Media, 2013.

Purwanto, M. Ngalim. Administrasi Dan Supervisi Pendidikan. Bandung: Remaja Rosdakarya, 2010.

Rohiat. Manajemen Sekolah. Bandung: PT. Refika Aditama, 2010.

Sudarsana, I Ketut. "Peningkatan Mutu Pendidikan Luar Sekolah Dalam Upayapembangunan Sumber Daya Manusia." Jurnal Penjaminan Mutu 1, no. 1 (2016): 1. https://doi.org/10.25078/jpm.v1i1.34.

Sukmadinata, Nana Syaodih, Ayi Novi Jami'at, and Ahman. Pengendalian Mutu Pendidikan Sekolah Menengah: Konsep, Prinsip, Dan Instrumen. Bandung: Refika Aditama, 2006.

Suparlan. Menjadi Guru Efektif. Yogyakarta: Hikayat Publishing, 2005.

Thoha, Mohammad. Manajemen Penddikan Islam Konseptual Dan Operasional. Surabaya: Salsabila Putra Pratama, 2016.

Wakiah, Maryatul, and Jamiludin Usman. "Manajemen Peningkatan Mutu Kompetensi Lulusan Bidang Kewirausahaan Dalam Memenuhi Standar Nasional Pendidikan Di Smk Annuqoyyah Guluk-Guluk Sumenep Jawa Timur." Re-JIEM (Research Journal of Islamic Education Management) 3, no. 1 (2020): 71. https://doi.org/10.19105/re-jiem.v3i1.3517.

Wirawan. Evaluasi Kinerja Sumber Daya Manusia Teori, Aplikasi,Dan Penelitian. Jakarta: Selemba Empat, 2009. 